\title{
Effect Financial Ratio, Company Age, Size Public Accountant Firm In Audit Delay
}

\author{
Julia \\ Accounting Department, Faculty of Economics, University of the Pacific Islands \\ Email: saputrajulia07@gmail.com
}

\begin{abstract}
The accuracy in submission of financial statements is a condition where the company must accurately and timely calculate the report before being audited by public accountants. The purpose of this study was to Determine the effect of profitability, solvability, liquidity, company age and size of the public accounting firm with size as control variables on audit delay either simultaneously or partially. The population in this study was the mining companies listed on the Indonesia Stock Exchange in 2015-2017 and used 37 samples companies. The statistical analysis used in this study was the data panel regression analysis and continued testing of hypotheses with EViews version 9.0 software program. Based on the results of the analysis, it was concluded that the variable of profitability, liquidity, and age of company had no significant effect on audit delay. solvability, size of public accounting firm, and company size had a significant effect on audit delay.
\end{abstract}

Keywords: Profitability, Solvability, Liquidity, Company Age and Size, Audit Delay.

Abstrak: Keakuratan dalam penyampaian laporan keuangan adalah suatu kondisi di mana perusahaan harus secara akurat dan tepat waktu menghitung laporan sebelum diaudit oleh akuntan publik. Tujuan dari penelitian ini adalah untuk menentukan pengaruh profitabilitas, solvabilitas, likuiditas, usia perusahaan dan ukuran kantor akuntan publik dengan ukuran sebagai variabel kontrol pada audit delay baik secara simultan atau sebagian. Populasi dalam penelitian ini adalah perusahaan pertambangan yang terdaftar di Bursa Efek Indonesia pada tahun 2015-2017 dan menggunakan 37 perusahaan sampel. Analisis statistik yang digunakan dalam penelitian ini adalah analisis regresi data panel dan pengujian lanjutan hipotesis dengan program perangkat lunak Eviews versi 9.0. Berdasarkan hasil analisis, disimpulkan bahwa variabel profitabilitas, likuiditas, dan umur perusahaan tidak berpengaruh signifikan terhadap audit delay. Solvabilitas, ukuran kantor akuntan publik, dan ukuran perusahaan memiliki pengaruh signifikan terhadap audit delay.

Kata kunci: Profitabilitas, Solvabilitas, Likuiditas, Umur dan Ukuran Perusahaan, Audit Delay.

\section{INTRODUCTION}

Delay in the completion of financial statements often creates problems whose effects cannot be avoided just like a company, such as the audit process will be delayed. The 
postponement of the completion of the financial statements will have an impact on the financial performance of an entity compiled by the company's management to the parties concerned both internal and external parties. Therefore, the financial report is not only a report of the responsibility of the Board of Directors and the Board of Commissioners in carrying out the management and supervision of issuers or public companies to the GMS, but is also an important source of information for investors or shareholders, including foreign investors or shareholders in taking investment decisions and means of controlling shareholders of issuers or public companies.

In 2017 AISA management appointed PT Ernst and Young Indonesia (PT EY) to examine the company's financial statements in 2017, which were then still being managed by AISA's old management. The results were found to have inflated funds of up to Rp4 trillion. Therefore, the disclosure of information on AISA on October 24, 2018, the audit itself is the mandate of the results of the Extraordinary General Meeting of Shareholders (EGMS) which asks management to appoint a public accounting firm (KAP) and or independent legal consultant to conduct an investigative audit of 2017 AISA financial statements.

In 2018, 24 issuers or companies listed on the Indonesia Stock Exchange (IDX) will be sanctioned by the stock exchange authorities for not submitting financial reports. There are 714 companies listed on the Indonesia Stock Exchange (IDX), of which 692 companies must submit audited financial statements for the period 2018. The Indonesia Stock Exchange has sent a written warning to companies that have not submitted financial reports. A company whose bankruptcy was recently hit by a bankruptcy decision, PT Tiga Pilar Sejahtera Food Tbk (AISA), included in the issuers of money has not yet reported the company's performance last year, not only annual financial reports, but also interim financial reports.

Whereas in the following year the Indonesia Stock Exchange (BEI) noted only 578 listed companies submitted financial statements for the first semester of 2019 on time. Until now, the total number of companies listed on the IDX is 737 companies. This means that only $78.4 \%$ of the total issuers reported their financial statements in the first semester of 2019 on time. In addition, there was also one company late submitting disclosure of written information to the Exchange on the audit plan or review, which was subject to written warning, namely PT Dian Swastatika Sentosa Tbk (DSSA). A different listed company whose book year ends in March and has not yet submitted its financial statements by 31 July is subject to written warning I, namely PT Renuka Coalindo Tbk (SQMI).

In Indonesia, the accuracy of financial reporting by companies that went public in the compulsory to submit annual financial statements accompanied by the auditor's report with unqualified opinion to the Financial Services Authority (FSA, d / h Bapepam-LK) no later than the end of the fourth month following the date Annual finance report. It is listed in the Decision of the Capital Market Supervisory Agency: KEP-431 / BL / 2012 XK6, followed by Rule Financial Services Authority (FSA) No. 29 /PJOK.04/2016 Chapter III Article 7 of the obligation to submit annual financial statements of the company is 4 months or 120 days after the date of expiry of the fiscal year.

This research was supported by the phenomenon of companies that in the suspension by the Indonesia Stock Exchange due to the delay in presenting the company's financial statements. This becomes a serious problem for responding because of suspension made 
by the Indonesia Stock Exchange in continuing to lead the company in question in delisting. As was the case in PT. Coral Berau Energy Tbk engaged in coal mining which has been in suspension by the Indonesia Stock Exchange since May 4, 2015 for not delivering the interim financial statements June 30, 2015 and has not paid the penalty for late before (Source: $\underline{w w w . i n d o p r e m i e r . c o m}$ ).

In general, investors consider that the late submission of financial statements is a bad sign for the health condition of the company. The level of profit and survival of the company is disrupted so that it requires a level of accuracy and accuracy at the time of the audit process that will cause audit delay. According to Malinda (2015) Audit delay is the length of time between the end of the company's fiscal year to the date of the audit report that is measured quantitatively (number of days). Profitability is the company's ability to benefit from its business. Solvency is a ratio used to measure the extent to which a company's assets are financed with debt, meaning how much debt burden is borne by the company compared to its assets. Liquidity is a ratio that illustrates the company's ability to meet short-term obligations (debt). The age of the company is how long a company is able to survive, compete and take business opportunities that exist in the economy. Public accounting firm is a form of public accounting organization that obtains a business license in accordance with statutory regulations, as a forum for public accountants in providing their services, that the size of the public accounting firm is grouped into two groups, namely the big four and non big four.

According to Tiono (2013), the size of a company indicates the size of a company. Accuracy in the delivery of financial statements is a condition where companies must calculate accurately and timely in publishing their reports before being audited by a public accountant. Associated with making decisions that will see from the financial statements submitted. That way, there are several things that affect the delay in the submission of financial statements and important factors that also affect it and become one of the objects of research to be investigated. Important factors to be tested in this study are Profitability, Solvency, Liquidity, Age of the company and the size of the public accounting firm and the size of the company which is the control variable in this study.

Research Objectives. The aim of this research is: (1) To identify empirically the effect of profitability audit delay in mining companies listed on the Indonesia Stock Exchange 2015-2017. (2) To identify empirically the effect of the solvency of the audit delay in mining companies listed on the Indonesia Stock Exchange 2015-2017. (3) To identify empirically the effect of likuiditasterhadap audit delay in mining companies listed on the Indonesia Stock Exchange 2015-2017. (4) To identify empirically the effect of the age of the company audit delay in mining companies listed on the Indonesia Stock Exchange 2015-2017. (5) To identify empirically the effect of the size of the public accounting firm to audit delay in mining companies listed on the Indonesia Stock Exchange 2015-2017. (6) To identify empirically the effect of firm size as a control variable to audit delay in mining companies listed on the Indonesia Stock Exchange 2015-2017.

\section{THEORETICAL REVIEW}

Theory Entities (Entity Theory). Theory Entities emphasizes the concepts " stewardship " management and responsibility " accountability " where business is concerned with the 
level of business continuity and financial information business for the owner's equity in order to meet legal requirements and management of a good relationship with equity holders in the hope that easy to obtain future financial needs (Tandiontong, 2016).

Theory Agency. According to (Tandiontong, 2016), which looked Theory Agency (Agency Theory) as a version of game theory makes a contractual model between two or more people (parties), where one party called the agent and the other is called the principal.

Theory of Compliance. According (Widjaja, 2015), obedience or adherence to a review of the audit on financial controls and operations and transactions to their compatibility with the rules, standards, and procedures. Compliance is a form of research in implementing orders. Compliance came from the word obedient.

Financial statements. In practice the financial statements by the company are not made in a state of emergency, but it must be made and prepared in accordance with the applicable rules or standards. This is necessary so that the financial statements easier to read and understand. The financial statements presented are very important for the management company and owner of the company. Besides, many of those who need and interest in the financial statements that the company, like the government, creditors, investors, and suppliers. The financial statements as a source of information must meet several requirements in order that wisdom is taken based on the information that is misleading. As for the conditions as stipulated in the exposure draft of the Indonesian Accounting Principles include: 1) relevant, 2) Understandably 3) Power Test.

Examination of Financial Statements by Certified Public Accountants. In practice, financial statements by companies are not made in urgent circumstances, but must be prepared and arranged in accordance with applicable rules or standards. This needs to be done so that the financial statements are easy to read and understand. The financial statements presented by the company are very important for management and company owners. In addition, there are many parties who need and have an interest in the financial statements made by companies, such as the government, creditors, investors, and suppliers. Financial statements as a source of information must meet several requirements so that the policies taken based on that information are misleading. The requirements as stated in the exposure draft of Indonesian Accounting Principles include: 1) Relevant, 2) Understanding 3) Test Power, 4) Neutral 5) On Time, 6) Comparability and, 7) Complete. According to (Hery, 2013), the financial statements that have been vetted by a public accountant is more important because the report has been compared or matched with records accounting by independent accountants to the management of public company.

The Accountant after conducting research with the standards and audit procedures will will give its opinion fairness of financial statements presented by the company, the balance sheet and income statement, that the report in accordance with accounting principles prevalent and have been applied consistently from year to year (Wardhani, Awaluddin, \& Reniati, 2019) 


\section{Audit Concept}

Definition of Audit. Auditing is a systematic process to obtain and assess the evidence objectively, relating to the assertion-assertion of the actions and events of the economy to determine the degree of correspondence between assertions-assertions with established criteria and communicating the results to the parties- interested parties (Barry and Puspa, 2013).

The concept of Auditing Standards. Auditing standards differ from audit procedures. " Procedure " relates to actions to be implemented, while the " Standard " with regard to the criteria of performance or quality measurements such action and related to the objective to be achieved through the use of these procedures (PSA 1, Standard Audit Section 150). Auditing standards that have been established and endorsed by the Indonesian Institute of Accountants in 2001 consists of ten standards are grouped into three major groups, namely: (1) the general standard (2) the standard of field work, and (3) reporting standards.

Audit Report. Laporan audit is one important step in the audit process. At this stage an internal auditor is required to mix and process the raw materials obtained during the audit field into a report that will fit the needs of management (Widjaja, 2015). The report is very important in the audit assignment for communicating the findings of the auditor.

Audit Delay. Audit delaydelays in completion of the audit is to be calculated by the difference between the date of signing of the independent audit report by the closing date of annual financial statements (Angruningrum and Wirakusuma, 2013). Audit is this delay which could affect the accuracy of information published, so it will affect the level of uncertainty decision based on the information published.

Profitability. Profitability is the company's ability to benefit from his efforts. Here the problem is management effectiveness in using both total assets and net assets. Effectiveness was assessed by linking return on assets used to generate profit (Sunyoto, 2013).

Solvency. Solvency is a ratio used to measure the extent of the company's assets are financed by debt, that is how big the debt burden borne by the company as compared to its assets. In a broader sense it is said that solvency is used to measure a company's ability to pay all its obligations, both short- and long-term if the company is dissolved (Kashmir, 2013).

Liquidity. According (Aryefiansyah, 2013) mentions that liquidity is a ratio that illustrates the company's ability to meet obligations (debt) short-term. That is, if the company is billed, the company will be able to meet its debt especially debt that is due.

Age Company. Age of the company is the length of the company is operating. Referring to previous research conducted by (Saemargani, 2015) Age company from the date of establishment of the company until the closing date of the company. Age company also applied to things that would be considered investor in making an investment, and also 
reflects the companies survive and be proof that the company is able to compete and be able to take business opportunities in the economy.

Size of Public Accounting Firm (KAP). Public accounting firms are a form of organization of public accountants who obtain a license in accordance with the legislation, as a forum for public accountants in providing services, that the size of public accounting firms are grouped into two groups: on the big four and non big four. According Lucyanda (2013: 138) states that the variable size of the public accounting firm is measured by using a dummy where public accounting firm included The big four (1) and non big four (0).

Company size. According (Tiono and Julius, 2013), firm size shows the size of a company. A company can be said to be large or small viewed from several perspectives such as total assets, total sales, total employment and so on. Companies that have the resources (assets) is large has one main characteristic is the existence of supervision of investors, regulators and the public spotlight.

Research Accomplished. This research is research that draws on research Barjono (2018) with the title of the study effect of firm size, profitability, solvency, the auditor's opinion, and the quality of auditors, to audit delay on coal mining company listed on the Indonesia Stock Exchange from 2012 to 2016. Variables to be studied in contrast to previous research. The variable in this study is liquidity, the Company Age, Size of Public Accounting Firm (KAP), and the size of the Company.

Framework Thought. Overall, it can be formulated framework of thinking as follows:

Figure 1. Framework Thought

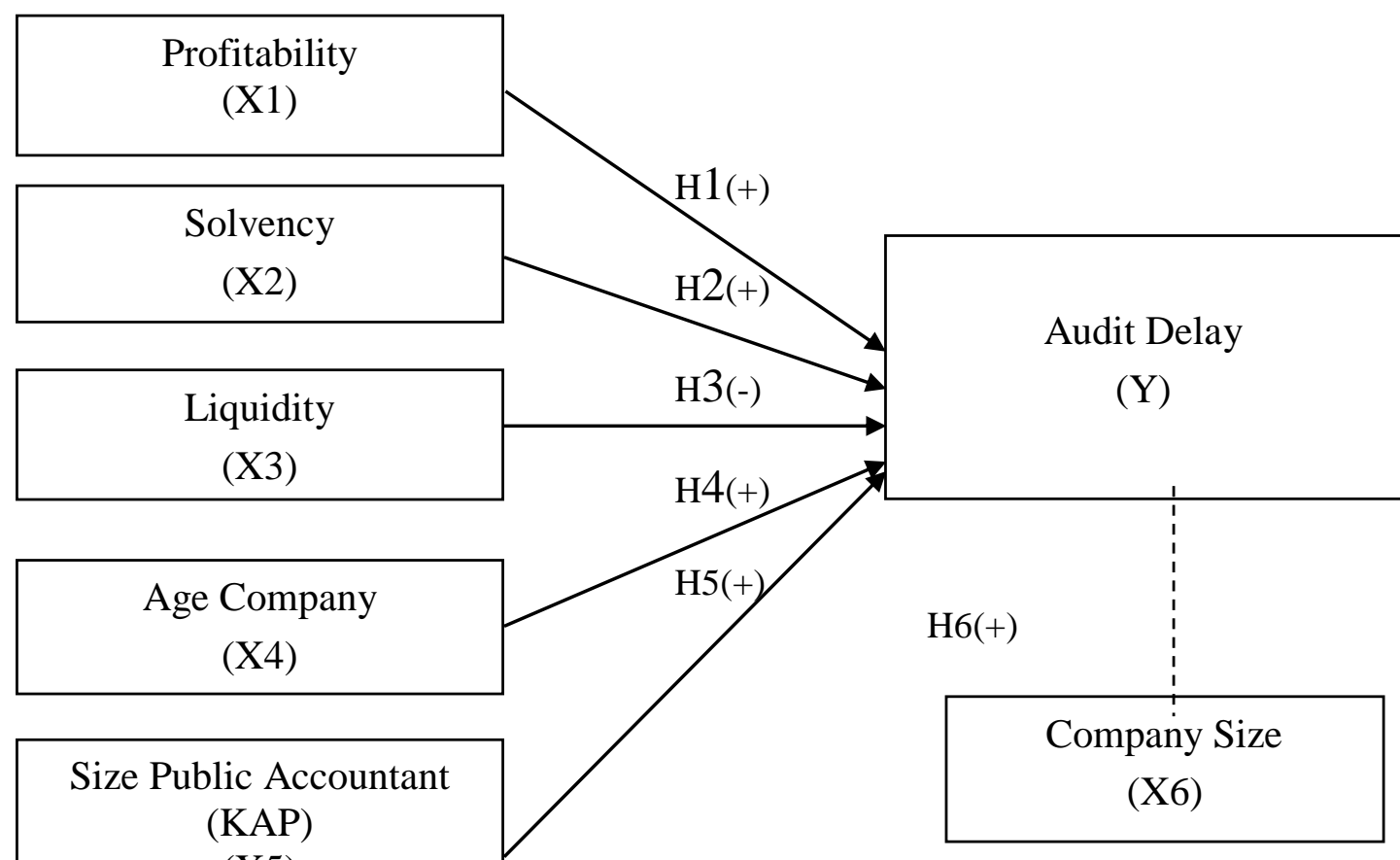

(X5)

Source: (Data processed researcher, 2019) 
Hypothesis. Old or not the audit delay that occurs will affect the decision of investors due to the delay of information to investors will affect investor confidence in capital markets. The financial report is a bridge between enterprise information with outside parties. But management companies often make efforts so that the financial statements published by the company looked good, it is commonly called window dressing (Khoirul Muhammad Anam, 2017). To that end, the late submission of financial statements often be one of the factors causing it. So in this case the late submission of financial statements may be influenced by several variables that exist in this study. Based on the theoretical framework of ideas and the results of previous studies:

H1 : Profitability and Significant positive effect on audit delay.

H2 : Solvency positive and significant impact on audit delay.

H3 : Liquidity negative and not significant to the audit delay.

H4 : Age of the company and significant positive effect on audit delay.

H5 : The size of the public accounting firm (KAP) positive and significant impact on audit delay.

H6 : The size of the company and significant positive effect on audit delay.

\section{METHODOLOGY}

Research methods. Quantitative research is a research method based on the philosophy of positivism, used to examine populations or specific samples, collecting data using research instruments, analyzing quantitative or statistical data with the aim of testing hypotheses that have been established (Sugiyono, 2017).

Population and Sample. The population in this study is a mining company listed on the Indonesia Stock Exchange (BEI) in 2015, 2016 and 2017. According to (Jogiyanto, 2013), purposive sampling sampling technique is done by taking a sample of the population based on criteria terntentu. The criteria used may be a consideration (judgment) or a certain quota (quota). The samples in this study were 37 mining companies listed on the Indonesian Stock Exchange (BEI) in 2015, 2016 and 2017.

Data collection technique. Data collection techniques used in this study is the method of documentation. Documents cited in this research is the company's annual financial statements and financial reporting of data that the research samples. Collecting data in this study were obtained from the financial statements of mining companies registered in BEI period 2015 through to 2017, published in the (www.web.idx.id) and (www.idx.co.id).

\section{Operational Definition and Measurement of Variables}

The dependent variable (Dependent Variable). audit delay an important aspect in maintaining the relevance of the information required by users of financial statements. Audit delay is an important aspect in maintaining the relevance of information needed by users of financial statements. The length of time the audit is measured from the closing 
date of the financial year to the date of issuance of the audit report is called audit delay (Dewi, 2013).

\section{Variables (Independent Variable)}

Profitability. The better the profitability ratio, the better illustrate the ability of the high profitability of the company. Potential investors will carefully analyze the smoothness of a company and its ability to make a profit. The better the profitability ratio, the better the ability to describe the high profitability of the company (Fahmi 2013).

Solvency. Solvency is the ability of the company to meet financial obligations or debts, both short term liabilities and long-term (Hery, 2015).

Liquidity. Liquidity can be defined as the level of ability of a company to be able to pay its debts that have matured (Kashmir, 2015). A Company has the power to pay not necessarily able to meet all its financial obligations.

Age Company. Companies with age has been a long time will be better, faster, and accurate in processing, collecting, activities and giving the necessary information for the auditor. Companies that have an older age tend to be skilled in collecting, processing and produce information when needed, karenaperusahaan has gained considerable experience. This will certainly speed up the audit process that ultimately affect audit delay.

Size of Public Accounting Firm (KAP). Size of Public Accounting Firm (KAP) also factored into the length and timeliness of audit delay the publication of the financial statements. This is because the larger the firm means the resulting audit quality tends to be better than the small accounting firm (Ratnasari, 2017).

variable Control. The size of the company is a value that indicates how much capacity the company. Size companies generally proxied by total assets. Total assets menggaambarkan amount of property owned by the company the larger the size of the company (Lucyanda and Auditing, 2013).

Data analysis technique. The analysis technique used in the study uses panel data regression methods. According to Ghozali (2017), panel data is data that has a combination of two elements, namely time series data and cross section data. Panel data regression analysis in this study was used to determine the effect of profitability, solvency, liquidity, company age, and the size of the public accounting firm (KAP) and company size as a control variable on audit delay on mining companies listed on the Indonesia Stock Exchange. Testing in this study was carried out in MS. Excel and Eviews 9.0. The method used in this study is the Fixed Effect (FE) or Fixed Effect Model Method.

To choose the fixed effect model, there are a number of tests on the eviews, namely the Chow Test or the Hausman Test. The chow test is the F Statistics test to choose whether the model used is pooled least square (PLS) or fixed effect. While the Hausman Test is to choose a fixed effect or random effect model. with the following research model : 


$$
Y_{i t}=\alpha_{1}+\alpha_{n} D_{n}+\ldots+\beta_{3} X_{3 i t}+\cdots+\beta_{n} X_{n i t}+\varepsilon_{i t}
$$

Descriptive Statistics. Descriptive Statistics are statistics used to analyze data by describing or describing data that has been collected as it is without intending to make conclusions that apply to the public or generalization (Sugiyono, 2017).

\section{RESULTS AND DISCUSSION}

\section{Descriptive Statistics Analysis}

Table 1. Descriptive Statistics Analysis

\begin{tabular}{cccccccc}
\hline & AD & ROA & SOL & CR & UMP & UKA & UKP \\
\hline Mean & 83,5 & 23,6 & 116,2 & 248,9 & 26,1 & 0,25 & 12,15 \\
\hline Maximum & 314,0 & 423,4 & 597,6 & 4713,73 & 49,0 & 1,00 & 16,5 \\
\hline Minimum & 38,0 & 72,13 & 1,93 & 1,23 & 8,0 & 0,0 & 9,6 \\
\hline
\end{tabular}

Source: (Data processed by Eviews 9.0, 2019)

Based on the above table shows that the minimum value of audit delay that occurs is 38 Descriptive statistical test results (Table IV.4) produced from 111 samples of mining companies listed on the Indonesia Stock Exchange from 2015 to 2017 show that the minimum audit delay value that occurs is 38 days, while the maximum value is 314 days and the average audit delay that occurred in this study period was 83.57 days or 84 days with a standard deviation of 42.63 . It can be seen that the maximum value of audit delay in this study shows that there are still mining companies that submit financial reports that are not timely or over 90 days. But on the other hand, this research shows that the average mining company has submitted financial reports in a timely manner or less than 90 days.

The profitability variable in this study has a minimum value of $-72.3 \%$, while the maximum value is $423.41 \%$ and the average profitability value in this study is $23.67 \%$ with a standard deviation of $66.12 \%$. The solvency variable in this study has a minimum value of $1.93 \%$, while the maximum value is $597.62 \%$ and the average value of profitability in this study is $116.26 \%$ with a standard deviation of $113.12 \%$. The liquidity variable in this study has a minimum value of $1.23 \%$, while the maximum value is $4713.73 \%$. and the average value of profitability in this study was $248.92 \%$ with a standard deviation of $494.98 \%$. For the age variable the company in this study has a minimum value of $8 \%$ while the maximum value is $49 \%$ and the average value of profitability in this study is $26.16 \%$ with a standard deviation of $11.79 \%$. For the variable size of the public accounting firm in this study has a minimum value of $0 \%$, while the maximum value is $1 \%$ and the average value of profitability in this study is $0.25 \%$ with a standard deviation of $0.43 \%$. The company size variable in this study has a minimum value of $9.65 \%$, while the maximum value is $16.55 \%$ and the average value of profitability in this study is $12.15 \%$ with a standard deviation of $1.23 \%$. 


\section{Classic Assumption Test}

Normality Test.The normality test aims to test whether in the regression model, confounding or residual variables have a normal distribution. As is known, that the fest and t test assumes residual values follow the normal distribution.

Heteroskidastity Test. Heteroscedasticity arises if the residual value of the model does not have a constant variance. That is, each observation has a different reliability due to changes in the underlying conditions not summarized in the model.

Table 2. Heteroskidastity Test

\begin{tabular}{cc}
\hline Variable & Value \\
\hline F-Statistics & 1.384724 \\
\hline Obs ${ }^{*}$ - -squared & 33.30183 \\
\hline Prob. Chi-Square & 0.1535 \\
\hline
\end{tabular}

Source: (Data processed by Eviews 9.0, 2019)

Based on the test results above show that the probability of the Chi-Squared $\geq 0$ 0:05 in the amount of 0.1535 means that there is no problem of heteroscedasticity in this study.

Multicolinearity Test. According to Imam Ghozali (2017), this test aims to test whether the regression model found an independent correlation between variables. A good regression model should not occur correlation between independent variables.

Table 3. Multicolinearity Test

\begin{tabular}{cc}
\hline & Centered \\
VIF \\
\hline Profitability & 1.111293 \\
Solvability & 1.100446 \\
Liquidity & 1.037808 \\
Company Age & 1.131726 \\
Public Accountant Size & 1.038318 \\
Company Size & 1.178899 \\
\hline
\end{tabular}

Source: (Data processed by Eviews 9.0, 2019)

Table 3. According to the table above shows that the data in this research model is not experiencing multicollinearities, indicated by VIF centered values that do not exceed 10.

Autocorrelation Test. The autocorrelation test aims to test whether in a linear regression model there is a correlation between the residual errors in the period $t$ and the errors in the $\mathrm{t}-1$ (previous) period. If there is a correlation, it is called an autocrelation problem. 


\section{Best Model Analysis \\ Test Chow}

Table 4. Chow Test

\begin{tabular}{cccc}
\hline Effect test & Statistic & d.f & Prob \\
\hline Cross-Section F & 2.496030 & $(36.68)$ & 0.0006 \\
Cross-Section Chi-Square & 93.482230 & 36 & 0.000 \\
\hline
\end{tabular}

Source: Data processed by Eviews 9.0, 2019

From the test results with chow above test results can be seen that the probability values Cross-Section F is $0.0006<0.05$ means Horejected. Thus Ha accepted, then according to the Chow test right model used in this panel data is the Fixed Effects Model.

\section{Test Hausman}

Table 5. Hausman Test

\begin{tabular}{cccc}
\hline Effect test & Chi-Sq.Statistic & Chi-Sq. d.f & Prob \\
\hline Cross-section Random & 19.555414 & 6 & 0.0033 \\
\hline
\end{tabular}

Source: (Data processed by Eviews 9.0, 2019)

Based on the above table, it is known probability value Crosssection $\mathrm{F}$ and Chisquare is equal to 0.0033 causing $\mathrm{H} 0$ is rejected and Ha accepted, because it is smaller than 0.05 Alpha. So based on Hausman test, the best model is to use a model Fixed Effect.

\section{Regression Analysis of Panel Data Model} Hypothesis testing

Tabel 6. Result of Model Estimation

\begin{tabular}{cccc}
\hline \multirow{2}{*}{ PAD } & \multicolumn{3}{c}{ Model } \\
\cline { 2 - 4 } & Common effect & Fixed effect & Random effect \\
\hline Constant & -24.43771 & 11.98759 & -48.96491 \\
Profitability & 0.7136 & 0.0755 & 0.7213 \\
Solvability & 0.4933 & $0.0434^{* *}$ & 0.8451 \\
Liquidity & 0.3529 & 0.2606 & 0.2718 \\
Company Age & 0.4357 & 0.1877 & 0.5182 \\
Public Accountant Size & 0.5949 & $0.0099^{* * *}$ & 0.2711 \\
Company Size & $0.0236^{* *}$ & $0.0282^{* *}$ & $0.0133^{*} *$ \\
R2 & 0.060868 & 0.595451 & 0.069802 \\
Adjusted $R$-squared & 0.006687 & 0.345582 & 0.016136 \\
Fstatistic & 0.353909 & 2.383053 & 1.300686 \\
\hline
\end{tabular}

Source: Data processed by Eviews 9.0, 2019 
Table 7. Result of Fixed Effect Model Estimation

\begin{tabular}{ccccc}
\hline \multirow{2}{*}{ Variable } & \multicolumn{5}{c}{ Fixed Model } \\
\cline { 2 - 5 } & Coefficient & Std. Error & T-Statistic & Prob \\
\hline Constant & 11.98759 & 146.2870 & 0.081946 & 0.9349 \\
Profitability & -0.169578 & 0.093947 & -1.805041 & 0.0755 \\
Solvability & 0.094439 & 0.045880 & 2.058383 & $0.0434 * *$ \\
Liquidity & 0.011424 & 0.010070 & 1.134497 & 0.2606 \\
Company Age & -5.569303 & 4.184549 & -1.330921 & 0.1877 \\
Public Accountant Size & 57.07207 & 21.49808 & 2.654751 & $0.0099 * * *$ \\
Company Size & 15.88690 & 7.086230 & 2.241940 & $0.0282 * *$ \\
R2 & 0.345582 & & & \\
Adjusted $R$-squared & 2.383053 & & & \\
$F_{\text {statistic }}$ & 0.000697 & & & \\
\hline
\end{tabular}

Source: (Data processed by Eviews 9.0, 2019)

The coefficient of determination $\left(\mathbf{R}^{2}\right)$. based on The estimation results fixed effect model of table above shows the determination coefficient of independent variables which include, profitability, solvency, liquidity, firm age, firm size, firm size able to explain the dependent variable audit delay, amounting to $34.55 \%$, it can be determined based on the value of Adjusted R Square of 0.345582 , while $65.45 \%$ are other factors that are not described in this study.

Test Simultaneous significant (Test StatisticF). The F statistical test basically shows whether all the independent variables entered in the model have a joint or simultaneous influence on the dependent variable (Ghozali 2017). The F statistical value and the value of statistical probability F in Table IV.10 This study is 2.383053 with probability 0.000697 , The F statistical probability value is less than the significant value of $\alpha=5 \%$, it can be concluded that the $\mathrm{HO}$ is rejected and $\mathrm{Ha}$ accepted. Thus, the independent variable in this study is profitability, solvency, liquidity, firm age, firm size, firm size as control variables together significantly affect audit delay dependent variable.

Significant Test of Individual Parameters (Test statistic t). The t-test statistic basically shows how far an independent variable is to the dependent variable by assuming that the other independent variables are constant (Ghozali 2017)

Result Discussion and Hypothesis Testing. Profitability of Audit Delay. The coefficient value is -0.169578 with a probability value of 0.0755 . this means that if there is an increase in profitability of $1 \%$ it will be followed by an increase in audit delay of 0.07550 
or by $0.07550 \%$ this shows that profitability does not significantly influence audit delay. Profitability is the company's ability to benefit from its business. The effectiveness of management in using assets to make a profit (Sunyoto, 2013). Such a relationship is one of the analyzes that gives a better picture even though the nature and timing of the value stated in the balance sheet will tend to distort the results. The results of this study prove that profitability does not affect audit delay, this indicates that audit delay is not influenced by the high or low level of profitability of a company. The results of this study are consistent with research (Debbianita, 2017; Allaily, 2017; and Lestari, 2018) which shows that profitability does not significantly influence audit delay.

Solvability coefficient value of 0.094439 with a probability value of 0.0434 , this means that if there is an increase in solvency of $1 \%$, it will be followed by an increase in audit delay of 0.0434 or by $0.0434 \%$. This shows that solvency significantly influences audit delay. Solvency is a ratio used to measure the extent to which a company's assets are financed with debt, meaning how much debt burden is borne by the company compared to its assets. In a broad sense it is said that solvency is used to measure the company's ability to pay all of its obligations, both short-term and long-term if the company is dissolved (Kasmir, 2013).

The results of this study prove that solvency affects audit delay, this indicates that audit delay is influenced by the high or low level of solvency of a company or the company's ability to return debt, because it is related to the company's going concern in the future.

The results of this study prove that solvency affects audit delay, this indicates that audit delay is influenced by the high or low level of solvency of a company or the company's ability to return debt, because it is related to the company's going concern in the future. The results of this study are consistent with research (Lestari, 2018) which shows that solvency has a significant effect on audit delay.

Liquidity Against Audit Delay. Liquidity coefficient value is 0.011424 with a probability value of 0.2606 . This means that if there is an increase in liquidity of $1 \%$, it will be followed by an increase in audit delay of 0.2606 or by $0.2606 \%$. This shows that liquidity has no significant effect on audit delay. The company's inability to pay its obligations, especially short-term debt (which is due) is caused by various factors. The results of this study prove that liquidity does not affect audit delay, this indicates that audit delay is not influenced by the high or low level of a company's liquidity. The results of this study are consistent with research (Karyadi, 2017) which shows that liquidity does not significantly influence audit delay.

Company Age Against Audit Delay. The value of the company's age coefficient of -5.569303 with a probability value of 0.1877 . This means that if there is an increase in company life by $1 \%$, it will be followed by an increase in audit delay of 0.1877 or by $0.1877 \%$. This shows that the age of the company does not significantly influence the audit delay. The age of the company is the length of time the company has operated. Referring to the previous research conducted by Saemargani (2015), the age of the company is calculated from the date of establishment of the company until the closing date of the company's books.

The company's inability to pay its obligations, especially short-term debt (which is due) is caused by various factors. The results of this study prove that liquidity does not 
affect audit delay, this indicates that audit delay is not influenced by the high or low level of a company's liquidity.

The results of this study prove that the age of the company does not affect audit delay, this indicates that audit delay is not influenced by the length of a company's standing. The results of this study contradict the research (Fauziyah, 2016; Karyadi, 2017) which shows that the age of the company has a significant effect on audit delay. KAP Size Against Audit Delay. KAP coefficient value of 57.07207 with a probability value of 0.0099 . This means that if there is an increase in KAP size by $1 \%$, it will be followed by an increase in audit delay of 0.0099 or $0.0099 \%$. This shows that KAP size significantly influences audit delay. Public accounting firm is a form of public accounting organization that obtains a business license in accordance with statutory regulations, as a forum for public accountants in providing their services, that the size of the public accounting firm is grouped into two groups, namely the big four and non big four. The results of this study are consistent with research (Kusumawardani, 2013) which shows that KAP size significantly influences audit delay.

\section{CONCLUSIONS}

Based on the analysis it is concluded that the profitability variables did not significantly affect audit delay, affects the audit delay solvency, liquidity no significant effect on audit delay, the age of the company does not have significant influence. In the audit delay, the size of the public accounting firm to audit delay significant effect, the size of the company significantly influence audit delay.

Suggestion. Further research is expected to use a variety of different types of sector companies as samples for further research that can be compared to the results of the audit delay problem.

Further research is expected to determine and discover new variables in this study, such an audit tenure, industry characteristics, internal audit, audit committees and others that can be used to test the audit delay.

Scope of problem. This study focuses on internal company factors such as profitability, solvency, liquidity, company age and company size as control variables in this study. Whereas for external factors in a company that is the size of a public accounting firm. These factors were chosen to be used as an independent variable and control of audit delay in mining companies listed on the Indonesia Stock Exchange in 2015-2017.

\section{REFERENCES}

Allaily, Anna, Asmaul Husna. (2017). " Factors affecting empirical audit delay studies on mining companies listed on the Indonesia Stock Exchange (BEI) in 2012-2015 ". Journal of Accounting \& Business, Faculty of Economics, Raja Ali Haji Maritime University.

Anam, M. K. (2017). "Determinants That Affect Audit Delay: Study of Companies Listed on the Indonesia Stock Exchange". Accountability: Journal of Accounting, Vol. 10, No. 1 
Angruningrum, S and Wirakusuma. (2013). " The Effect of Profitability, Leverage, Complexity of Operations, the Firm's Reputation and the Audit Committee on Audit Delay ". E-journals Akuntansi Universitas Udayana 5.2, hlm.251- 270.

Ariefiansyah, Ryan and Miyosi Margi Utami. (2013). Making Easy Financial Reports, Smart World Publishers, Jakarta.

Barjono and Mohamad Zulman Hakim. (2018). The Influence of Company Size, Profitability, Solvency, Auditor's Opinion and Auditor Quality on Audit Delay in Coal Mining Companies Registered in Bei 2012-2016. University of Muhammadiyah Tangerang.

Barry, Sekar and Puspa Wandanarum. (2013). Auditing Public Sector approach and Privat.Jakarta: Media Nation.

Debbianita, Stepphanie. (2017). "The Effect Of Profitability, Solvency, And Inventory Activity On Audit Delays In Retail Companies Listed On The Indonesia Stock Exchange In The 2014-2015 Period". Maranatha Accounting Journal Accounting Studies Program, Faculty of Economics, Maranatha Christian University Volume 9, Number 2, November 2017, pp 158-169.

Dewi, Sofia Prima and Jusia. (2013) "Factors Affecting the Timeliness of Delivering Financial Statements to Real Estate and Property Companies Listed on the IDX". Journal of Accounting, Volume 17 Number 3 pp. 368-384, Tarumanegara University, Jakarta.

Fahmi, Irham. (2013). Financial Statement Analysis. Bandung: Alfabeta.

Fauziyah Althaf, Amani. (2016). Effect of Company Size, Profitability, Audit Opinion, and Age of the Company on Audit Delay (Empirical Study of Property and Real Estate Companies Listed on the Indonesia Stock Exchange in 2012-2014). Nominal Journal / Volume V Number 1.

Ghozali, Imam and Dwi Ratmono (2017). Multivarat and Econometrics Analysis (Theory, Concepts and Applications, with Eviews 9). Semarang: Diponegoro Seamarang University Publisher Agency-ISBN: 978-602-097-2220.

Jogiyanto, Hartono. (2013). Business Research Methodology and Experience One Kaprahpegalaman.Edisi 5. BPFE-Yogyakarta. Yogyakarta.

Hersugondo and A. Kartika. (2013). "Predicted Probability Audit Delay and Determinannnya Factors ". No.35.Pp1-21.

Hery. (2013). Auditing (Accounting Examination I). Yogyakarta: CAPS (Center of Academic Publishing Service).

Karyadi and Muhamad. (2017). " Analysis of the effect of liquidity, profitability and solvency on audit delay case studies in ceramics, porcelain and glass sub-sectors listed on the Indonesia Stock Exchange in 2012-2016 '. Journal of Accounting, Gunung Rinjani University.

Kasmir. (2013). Analysis of Financial Statements (1.Cetakan 6th Edition). Jakarta: Rajawali Pers.

Kasmir. (2015). Analysis of the financial statements. Jakarta: Rajawali Pers.

Kusumawardani, Fitria. (2013)." Factors affecting audit delay in manufacturing companies and various industries which are listed on the Indonesia Stock Exchange as well as various industries (2012). Journal of Accounting, State University of Semarang AAJ 2 (1). 
Lestari Yunindiah, Syarifa,. (2018). "Factors Affecting the audit delay and Its impact on abnormal returns in the Indonesia Stock Exchange." International Journal of Economics and Finance; Vol.10, No.2: 2018.ISSN 1916-971X E-ISSN 1916-9728.

Lucyanda, J and Nura'ni. (2013). " Testing the factors that influence the Audit Delay ". EJournal of accounting \& auditing, Bakrie University Jakarta Vol: 9 No. 2 of 2013.

Malinda Dwi Aprilianie. (2015). Analysis of factors that affect audit delay (Empirical studies on mining companies listed on the Indonesia Stock Exchange Year 2008 to 2013). Yogyakarta State University. Thesis. Not published.

Ratna Sari, Aprilia. (2017). The Effect of Independence and Audit Situation on the Accuracy of Granting Audit Opinions with Audit Fees as a Moderating Variable (Case Study in KAP in East Jakarta), Journal of Managerial Accounting 2.1 (2017), 50-62; ISSN (E): 2502-6704.

Saemargani, F.I. (2015). " The effect of company size, company age, profitability, solvency, KAP size, and auditor's opinion on audit delay '.' Nominal Journal, 4 (2), $1-15$.

Sugiyono. (2017). Quantitative Research Methods, Qualitative, R \& D.Bandung: Alfabeta. Sunyoto, Danang. (2013). Financial Statement Analysis for Business (Theory \& Kasus.Yogyakarta: CAPS (Center of Academic Publishing Service).

Tandiontong, Mathius. (2016). Audit Quality and Measurement. Bandung: Alfabeta.

Tiono, Ivena and Julius Jogi C. (2013). " Factors Affecting Audit Report Lag In Indonesia Stock Exchange ". Business Accounting Review.Vol. 2, Pg. 286-298.

Wardhani, R. S., Awaluddin, M., and Reniati. (2019). Financial Performance and Corporate Social Responsibility on Return of Shares. Jurnal Akuntansi Universitas Tarumanagara, XXIII(03), 409-432.

Widjaja Tunggal, Amen. (2015). Understanding Internal and Operational Auditing. Jakarta: Harvarindo. 